\title{
ANALYSIS OF SERVICE QUALITY BASED ON PATIENT'S ASSESSMENT AND EXPECTATION IN MOTHER AND CHILD HOSPITAL OF SURABAYA
}

\author{
Peningkatan Kualitas Pelayanan Berdasarkan Penilaian dan Harapan Pasien di \\ Rumah Sakit Ibu dan Anak Surabaya
}

*Andini Yulina Pramono

College of Health and Medicine, Australia National University, Australia

${ }^{*}$ Correspondence: andiniyulina@yahoo.co.id

\begin{abstract}
Background: Service quality at Kendangsari Merr Mother and Child Hospital is expected to compete with other private hospitals, especially maternity hospitals. Nevertheless, several months after its opening, the hospital received a few complaints from its patients.

Aims: This study analyzed patient satisfaction to increase the service quality at Kendangsari Merr Mother and Child Hospital using RATER parameters.

Methods: This study was an observational study that used a cross-sectional design. It was conducted at Kendangsari Merr Mother and Child Hospital from 27 to 31 October 2014. The respondents were taken from a total population of all inpatients and outpatients during the survey. The instrument used was a questionnaire using service quality indicators, such as Reliability, Assurance, Tangible, Empathy and Responsiveness (RATER) parameters.

Results: The respondents' assessment of the service quality at Kendangsari Merr Mother and Child Hospital was good with an average score of $81 \%$. In terms of assurance, tangible, and empathy factors, most of the patients assessed that they received better services than what they expected.

Conclusion: Some other poor aspects of the service quality should be improved. They include the punctuality of doctor practice, doctors' skills, public facilities, politeness and awareness of staff pharmacists in treating patients' drugs as prescribed.
\end{abstract}

Keywords: assessment, expectation, patient satisfaction, service quality.

\section{ABSTRAK}

Latar Belakang: Kualitas pelayanan di Rumah Sakit lbu dan Anak Kendangsari Merr diharapkan mampu bersaing dengan rumah sakit swasta lainnya, terutama rumah sakit khusus ibu dan anak. Namun demikian, dalam usia beberapa bulan operasional, Rumah Sakit Ibu dan Anak Kendangsari Merr mendapatkan beberapa keluhan dari pasien.

Tujuan: Tujuan penelitian ini adalah untuk menganalisis kepuasan pasien dalam rangka meningkatkan kualitas pelayanan Rumah Sakit Ibu dan Anak Kendangsari Merr dengan menggunakan parameter RATER. Jenis penelitian ini termasuk penelitian observasional dan cross-sectional.

Metode: Penelitian dilakukan di Rumah Sakit Ibu dan Anak Kendangsari Merr mulai tanggal 27-31 Oktober 2014. Responden penelitian ini diambil secara total populasi. Responden merupakan pasien rawat jalan dan rawat inap di Rumah Sakit lbu dan Anak Kendangsari Merr pada saat kegiatan survei berlangsung. Instrumen yang digunakan dalam penelitian ini adalah kuesioner dengan menggunakan parameter indikator mutu pelayanan, yaitu: Reliability, Assurance, Tangible, Empathy dan Responsiveness.

Hasil: Hasil penelitian ini antara lain penilaian responden terhadap Rumah Sakit Ibu dan Anak Kendangsari Merr adalah baik yaitu sebanyak $81 \%$ responden. Dalam hal jaminan, berwujud, dan empati, sebagian besar pasien menilai bahwa mereka telah menerima layanan yang lebih baik dari apa yang mereka perkirakan.

Kesimpulan: Beberapa aspek lainnya yang masih rendah perlu ditingkatkan. Aspek tersebut meliputi ketepatan waktu praktek dokter, kemampuan dokter, fasilitas umum, kesopanan petugas farmasi dalam melayani kebutuhan pasien.

Kata kunci: harapan, kepuasan pasien, kualitas pelayanan, penilaian.

\section{INTRODUCTION}

Today's robust manufacturing causes an increased level of the national economy and citizen's income. Increased community income increases the demand for service products. With the increasing demand for service products, more and more service manufacturers start emerging. This increasing number causes intense competition, experienced by not only service companies or organizations, such as banks, telecommunication companies, and tourism agents but also by the 
education institutions, health providers, and so forth. Healthcare providers currently experience more fierce competition. Along with the rapid development of medical science and increasing human needs for health facilities, various health facilities have existed. Both the government and private sectors establish the infrastructure of health facilities, such as clinics and so on. Public and private health facilities compete with each other in improving services to the community. In addition, the developing mindset of the community has influenced them to critically choose health services to fulfill their needs. The Kendangsari Merr Mother and Child Hospital were established on August 8, 2014. The quality of the hospital service is expected to compete with other private hospitals, especially for maternity hospitals. However, during a onemonth operation, the Kendangsari Merr Mother and Child Hospital received several complaints from patients.

Therefore, this study aimed at analyzing patient satisfaction to improve the service quality of Kendangsari Merr Mother and Child Hospital by using the RATER parameters. Specifically, it identified the characteristics of respondents based on age, a number of children, the latest education, the latest education of their husband, employment, their husband's employment, monthly family income. Moreover, it explained the selection process of obstetric and childbirth services, including decision-making, looking for sources of information and priority factors. The RATER parameters were in use to assess the service quality at the hospital and respondents' expectations about the services.

\section{METHOD}

This study deployed a cross-sectional study because data were collected at a certain time. This study was an observational study conducted in Kendangsari Merr Mother and Child Hospital from 27 to 31 October 2014 without treatment for the samples. Respondents were taken from a total population of inpatients and outpatients at Kendangsari Merr Mother and Child Hospital during the survey. The instrument used was questionnaires which adopt the service quality parameters, including Reliability, Assurance, Tangible, Empathy, and Responsiveness (RATER) (Zeithaml, Parasuraman, and Berry, 2001).

This study consisted of several stages, such as 1) preparation of questionnaires as a tool for interviewing patients and/or their families, 2) data collection through an interview to respondents, 3) data entry to software, 4) data analysis, 5) preparation of strategic issues, 6) preparation of recommendations. Some of the stages can be explained briefly in Figure 1.

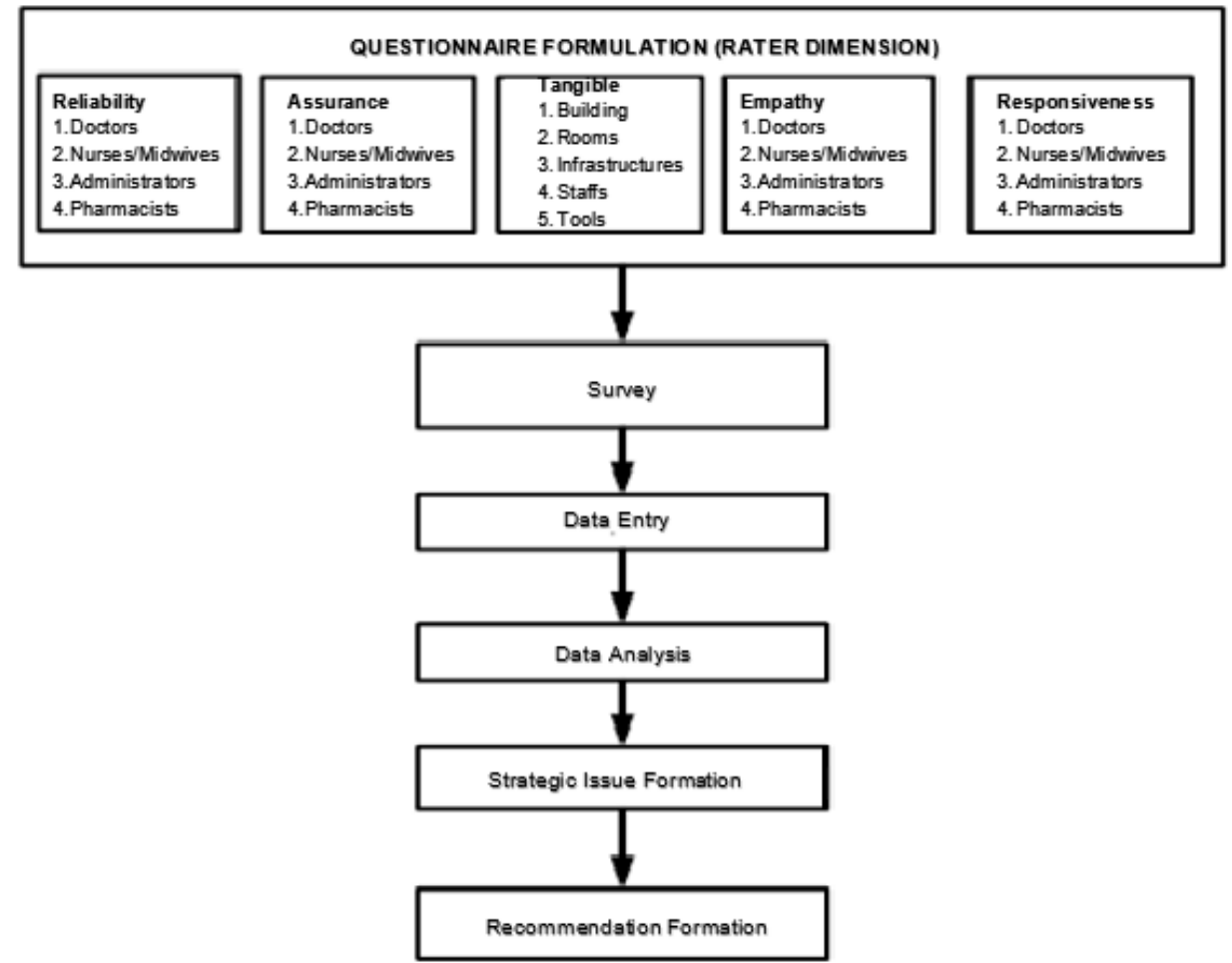

Figure 1. Research Framework

\section{RESULTS AND DISCUSSION}

The number of respondents was 42 people who were observed from their age, number of children, marital status, education, husband's education, work, husband's work, and family income. The majority of respondents were 26-30 years and married. As many as $57.1 \%$ of the respondents attained an undergraduate degree, and heir husbands mostly had a bachelor's degree 
(64.3\%). There were $33.3 \%$ of the respondents and $50 \%$ of their husbands who work in private sectors. The monthly family income of $28.6 \%$ of the respondents was IDR 2,500,000-5,000,000.

This section will discuss the respondents' behavior, such as decision-making and finding information as well as priority factors, in selecting obstetric and childbirth services. It was found that the decision-makers are the respondents' husbands $(59.5 \%)$ while most of the respondents got informed by the doctors about Kendangsari Merr Mother and Child Hospital (61.9\%). Based on this consideration, the respondents take the information from the doctors as a priority factor in selecting the maternity hospital.

As many as $57.1 \%$ of respondents have never used ob-gyn polyclinic services before, and $61.9 \%$ of respondents have never used child polyclinic services. There are $71.4 \%$ of respondents who have never given birth at Kendangsari Merr Mother and Child Hospital, and almost all respondents $(97.6 \%)$ have never used inpatient non-labor services. As many as $81 \%$ of respondents have never used inpatient services for children at Kendangsari Merr Mother and Child Hospital. Nearly $61.9 \%$ of respondents have utilized services for mother and child, and half of the respondents chose Kendangsari Merr Mother and Child Hospital as the first place. In terms of human resources, $45.2 \%$ of respondents chose the hospital because of staff friendliness. Meanwhile, the most disappointing services, such as unclean bathrooms and unavailability of soap and tissue, are accounted for by $9.5 \%$ of the respondents. More than half of respondents $(61.9 \%)$ utilized other health services outside Kendangsari Merr Mother and Child Hospital. Most of them have had a medical checkup at Putri Mother and Child Hospital and Kendangsari Merr Mother and Child Hospital. However, half of them prefer Kendangsari Merr Maternity Hospital to another hospital.

According to Narang et al. (2015), outcomes in health services have many interpretations. Reerink and Sauerborn (1996) considered death, illness, malnutrition, duration of pain, quality of life and satisfaction as the outcomes. Public health status, the number of deaths and Disability Adjusted-Life Year (DALY) are often used by governments and non-profit organizations to measure the outcomes. Meanwhile, the World Health Organization (2000) states that outcomes can be measured by the number of deaths, DALY, and responsiveness. On the other hand, patients see involved their differently, for example, satisfaction with patient visits to hospitals (Qatari and Haran, 1999). The World Health Organization regards patients' satisfaction as determining quality indicators.

The assessment of Kendangsari Merr Mother and Child Hospital was based on 5 aspects, such as Reliability, Assurance, Tangible, Empathy and Responsiveness. According to Zeithaml et al. in Tjiptono (2000), factors used to evaluate satisfaction in the health sector are reliability which includes promises and accurate diagnosis, assurance including skills, trust and reputation, and tangible (physical evidence) of treatment rooms and facilities. The two others are empathy by giving attention and friendly services to patients as well as responsiveness in handling patients' complaints and being in contact with patients.

Reliability assessment was carried out to doctors, nurses or midwives, administrative staffs and staff pharmacists. Doctors are evaluated from the way they provide services and treatment for patients on time in accordance with doctors' instruction, and clear examination of patients without differentiating their social status. Factors assessed from nurses were the punctuality of services and the quality of nursing/midwifery care without differentiating patients' social status. The assessment done to administrative staffs was seen from the ease and smoothness of admission procedures, and the details, precision, and manner of data recording. While staff pharmacists were assessed based on their explanation of a drug, including the dose, best times to take medicines, and clear information on drug purchase service.

Moreover, doctors, nurses or midwives, administrative staffs and staff pharmacists were assessed too to identify the aspect of assurance. In this case, the doctors were assessed based on the accuracy of the doctor's diagnosis and treatment as well as doctors' skills at work. Some factors of assurance assessed from the nurses/midwives included the performance of nursing/midwifery services, the skills of nurses/midwives in handling patients' needs and complaints. Meanwhile, the administrative staffs' assurance was seen from their ability to record patient data and their accuracy data entry. Also, the assurance of staff pharmacists was measured from the accuracy and clarity of prescribing and administering drugs.

The third assessed aspect is Tangible which can be seen from hospital buildings and the health workers. Factors assessed from hospital buildings included the comfort and modernity of the buildings, room decoration, room cleanliness, completeness and cleanliness of medical equipment, as well as public facilities (parking, lobby, waiting room and toilet). For the doctors, nurse/midwives, and administrative staffs, the assessment was based on their appearance, which is expected to be always neat and attractive. The assessment carried out for pharmacy measures the cleanliness and neatness of the pharmacy rooms, good drug packaging, and neat staff pharmacists' appearance.

The fourth aspect is empathy. For the assessment conducted to doctors, some assessed factors involved their ability to understand and respond to patients' complaints, questions and conditions. Similarly to doctors, nurses/midwives are assessed from the way they give services to patients and respond to patients' needs. Not far different from factors assessed for doctors and nurses, administrative staffs and staff pharmacists elaborates were evaluated from their kind response to patients' needs and questions.

The last aspect is the responsiveness. This aspect values the clarity of information that doctors provide and doctors' responsiveness to treat patients. Apart from the doctors' assessment, the performance of nurses/midwives assessed includes their responsiveness to patients' questions, 
complaints, and needs. The fourth done to administrative staffs covers their responsiveness and priority for the needs of patients and families. As staff pharmacists were also assessed, the number, type and expiration date of drugs were taken into evaluation. Table 1 illustrates the calculation of patients' assessment of these five aspects.

Table 1. Patients' Assessment and Expectations of Services at Kendangsari Merr Mother and Child Hospital.

\begin{tabular}{|c|c|c|c|c|c|c|}
\hline RATER & $\begin{array}{l}\text { Expectation } \\
\quad> \\
\text { Assessment } \\
\end{array}$ & $\%$ & $\begin{array}{l}\text { Expectation } \\
\quad= \\
\text { Assessment }\end{array}$ & $\%$ & $\begin{array}{l}\begin{array}{c}\text { Expectation } \\
< \\
\text { Assessment }\end{array} \\
\end{array}$ & $\%$ \\
\hline \multicolumn{7}{|l|}{ Reliability } \\
\hline $\begin{array}{l}\text { Doctors provide services without } \\
\text { differentiating patients' social } \\
\text { status }\end{array}$ & 8 & 19 & 14 & 33.3 & 20 & 47.6 \\
\hline $\begin{array}{l}\text { Doctors perform their practice on } \\
\text { time }\end{array}$ & 14 & 33.3 & 9 & 21.4 & 19 & 45.2 \\
\hline $\begin{array}{l}\text { Treatment to patients is based on } \\
\text { doctors' instruction }\end{array}$ & 9 & 21.4 & 11 & 26.2 & 22 & 52.4 \\
\hline $\begin{array}{l}\text { Patient treatment is clearly } \\
\text { informed }\end{array}$ & 10 & 23.8 & 11 & 26.2 & 21 & 50 \\
\hline $\begin{array}{l}\text { Nurses perform nursing care on } \\
\text { time }\end{array}$ & 9 & 21.4 & 11 & 26.2 & 22 & 52.4 \\
\hline $\begin{array}{l}\text { Nurses/midwives } \\
\text { nursing/midwifery care } \\
\text { differentiating pathorm } \\
\text { status }\end{array}$ & 6 & 14.3 & 16 & 38.1 & 20 & 47.6 \\
\hline $\begin{array}{l}\text { Patient admission procedures are } \\
\text { easy and accessible }\end{array}$ & 0 & 0 & 0 & 0 & 42 & 100 \\
\hline $\begin{array}{l}\text { Administrative staffs record } \\
\text { patients' data in proper, detailed, } \\
\text { and miticulous manner }\end{array}$ & 10 & 23.8 & 12 & 28.6 & 20 & 47.6 \\
\hline $\begin{array}{l}\text { Drug information, such as dose } \\
\text { and consumption, is clearly } \\
\text { informed }\end{array}$ & 10 & 23.8 & 14 & 33.3 & 18 & 42.9 \\
\hline $\begin{array}{l}\text { Drug purchasing procedure is } \\
\text { precisely in order }\end{array}$ & 12 & 28.6 & 12 & 28.6 & 18 & 42.9 \\
\hline \multicolumn{7}{|l|}{ Assurance } \\
\hline Doctors' diagnosis is correct & 12 & 28.6 & 14 & 33.3 & 16 & 38.1 \\
\hline Doctors' treatment skills are good & 14 & 33.3 & 9 & 21.4 & 19 & 45.2 \\
\hline Doctors' treatment is accurate & 12 & 28.6 & 14 & 33.3 & 16 & 38.1 \\
\hline $\begin{array}{l}\text { Nursing/midwifery care is } \\
\text { excellent }\end{array}$ & 4 & 9.5 & 18 & 42.9 & 20 & 47.6 \\
\hline $\begin{array}{l}\text { Nurses'/midwives' treatment skills } \\
\text { are good }\end{array}$ & 12 & 28.6 & 14 & 33.3 & 16 & 38.1 \\
\hline $\begin{array}{l}\text { Nurses/midwives can handle } \\
\text { patients' complaints }\end{array}$ & 11 & 26.2 & 15 & 35.7 & 16 & 38.1 \\
\hline $\begin{array}{l}\text { Administrative staffs' skills of data } \\
\text { record are good }\end{array}$ & 7 & 16.7 & 14 & 33.3 & 21 & 50 \\
\hline $\begin{array}{l}\text { Administrative staffs accurately } \\
\text { entry patient data }\end{array}$ & 9 & 21.4 & 15 & 35.7 & 18 & 42.9 \\
\hline $\begin{array}{l}\text { Staff pharmacists accurately } \\
\text { distribute drugs according to } \\
\text { prescription }\end{array}$ & 10 & 23.8 & 17 & 40.5 & 15 & 35.7 \\
\hline $\begin{array}{l}\text { Staff pharmacists accurately } \\
\text { distribute each patient's drugs }\end{array}$ & 11 & 26.2 & 17 & 40.5 & 14 & 33.3 \\
\hline \multicolumn{7}{|l|}{ Tangible } \\
\hline $\begin{array}{l}\text { Hospital's building is modern and } \\
\text { comfortable }\end{array}$ & 6 & 14.3 & 16 & 38.1 & 20 & 47.6 \\
\hline $\begin{array}{l}\text { Room decoration is neat and } \\
\text { interesting }\end{array}$ & 9 & 21.4 & 14 & 33.3 & 19 & 45.2 \\
\hline $\begin{array}{l}\text { Room cleaniness is well- } \\
\text { maintained }\end{array}$ & 8 & 19 & 16 & 38.1 & 18 & 42.9 \\
\hline $\begin{array}{l}\text { Medical instrument is complete } \\
\text { and clean }\end{array}$ & 9 & 21.4 & 15 & 35.7 & 18 & 42.9 \\
\hline Public facilities (parking, lobby, & 11 & 26.2 & 12 & 28.6 & 19 & 45.2 \\
\hline
\end{tabular}




\begin{tabular}{|c|c|c|c|c|c|c|}
\hline RATER & $\begin{array}{c}\text { Expectation } \\
> \\
\text { Assessment }\end{array}$ & $\%$ & $\begin{array}{c}\text { Expectation } \\
= \\
\text { Assessment }\end{array}$ & $\%$ & $\begin{array}{c}\text { Expectation } \\
< \\
\text { Assessment }\end{array}$ & $\%$ \\
\hline $\begin{array}{l}\text { waiting room, and toilet) are } \\
\text { complete }\end{array}$ & & & & & & \\
\hline $\begin{array}{l}\text { Doctors' appearance is } \\
\text { astonishing and neat }\end{array}$ & 7 & 16.7 & 14 & 33.3 & 21 & 50 \\
\hline $\begin{array}{l}\text { Nurses'/midwives' appearance is } \\
\text { astonishing and neat }\end{array}$ & 8 & 19 & 12 & 28.6 & 22 & 52.4 \\
\hline Nurses'/midwives' uniform is tidy & 9 & 21.4 & 13 & 31 & 20 & 47.6 \\
\hline $\begin{array}{l}\text { Administrative staffs' appearance } \\
\text { is astonishing and neat }\end{array}$ & 7 & 16.7 & 15 & 35.7 & 20 & 47.6 \\
\hline $\begin{array}{l}\text { Administrative staffs' uniform is } \\
\text { tidy }\end{array}$ & 7 & 16.7 & 15 & 35.7 & 20 & 47.6 \\
\hline $\begin{array}{l}\text { Pharmacy rooms are neat and } \\
\text { clean }\end{array}$ & 9 & 21.4 & 13 & 31 & 20 & 47.6 \\
\hline $\begin{array}{l}\text { Staff pharmacists' appearance is } \\
\text { astonishing and neat }\end{array}$ & 10 & 23.8 & 12 & 28.6 & 20 & 47.6 \\
\hline Drugs are well-packaged & 8 & 19 & 15 & 35.7 & 19 & 45.2 \\
\hline Empathy & & & & & & \\
\hline $\begin{array}{l}\text { Doctors respond patients' } \\
\text { complaint and condition well }\end{array}$ & 6 & 14.3 & 16 & 38.1 & 20 & 47.6 \\
\hline $\begin{array}{l}\text { Doctors are friendly to serve } \\
\text { patients }\end{array}$ & 4 & 9.5 & 17 & 40.5 & 21 & 50 \\
\hline $\begin{array}{l}\text { Doctors are willing to respond to } \\
\text { patients' questions }\end{array}$ & 5 & 11.9 & 17 & 40.5 & 20 & 47.6 \\
\hline $\begin{array}{l}\text { Nurses/midwives are patient in } \\
\text { performing nursing care to } \\
\text { patients }\end{array}$ & 4 & 9.5 & 18 & 42.9 & 20 & 47.6 \\
\hline $\begin{array}{l}\text { Nurses are responsive } \\
\text { patients' needs }\end{array}$ & 7 & 16.7 & 16 & 38.1 & 19 & 45.2 \\
\hline $\begin{array}{l}\text { Administrative staffs are friendly } \\
\text { in communicating with patients }\end{array}$ & 5 & 11.9 & 18 & 42.9 & 19 & 45.2 \\
\hline $\begin{array}{l}\text { Administrative staffs are polite in } \\
\text { serving patients }\end{array}$ & 5 & 11.9 & 19 & 45.2 & 18 & 42.9 \\
\hline $\begin{array}{l}\text { Administrative staffs are willing to } \\
\text { respond to patients' questions }\end{array}$ & 6 & 14.3 & 18 & 42.9 & 18 & 42.9 \\
\hline $\begin{array}{l}\text { Staff pharmacists are friendly in } \\
\text { distributing patients' drugs }\end{array}$ & 9 & 21.4 & 17 & 40.5 & 16 & 38.1 \\
\hline $\begin{array}{l}\text { Staff pharmacists are patient and } \\
\text { polite in responding to patients' } \\
\text { questions }\end{array}$ & 11 & 26.2 & 17 & 40.5 & 14 & 33.3 \\
\hline Responsiveness & & & & & & \\
\hline $\begin{array}{l}\text { Information for patients and their } \\
\text { family are clear }\end{array}$ & 6 & 14.3 & 16 & 38.1 & 20 & 47.6 \\
\hline $\begin{array}{l}\text { Doctors are responsive in treating } \\
\text { patients }\end{array}$ & 6 & 14.3 & 16 & 38.1 & 20 & 47.6 \\
\hline $\begin{array}{l}\text { Doctors respond to patients' } \\
\text { complaints and questions well }\end{array}$ & 8 & 19 & 15 & 35.7 & 19 & 45.2 \\
\hline $\begin{array}{l}\text { Nurses/midwives are aware in } \\
\text { giving fast-response to patients }\end{array}$ & 9 & 21.4 & 15 & 35.7 & 18 & 42.9 \\
\hline $\begin{array}{l}\text { Administrative staffs' } \\
\text { responsiveness to patients' and } \\
\text { their family's needs }\end{array}$ & 8 & 19 & 16 & 38.1 & 18 & 42.9 \\
\hline $\begin{array}{l}\text { Staff } \\
\text { responsiveness to patients' and } \\
\text { their family's needs }\end{array}$ & 8 & 19 & 17 & 40.5 & 17 & 40.5 \\
\hline $\begin{array}{l}\text { Staff pharmacists' attention to the } \\
\text { number, type, and expirate date } \\
\text { of drugs }\end{array}$ & 10 & 23.8 & 17 & 40.5 & 15 & 35.7 \\
\hline
\end{tabular}

Table 1 shows the reliability factors which most of the patients' assessment is higher than their expectations towards the services. As many as 14 people $(33.3 \%)$ thought that the doctors are not punctual in their practice. In addition, there were 2 respondents $(4.8 \%)$ who strongly disagreed and 1 respondent $(2.4 \%)$ who did not agree that the doctors provide services without differentiating 
patients' social status. Only one respondent $(2.4 \%)$ strongly disagreed that patients receive treatment according to the doctors' instructions. Meanwhile, only one respondent $(2.4 \%)$ strongly disagreed and 1 respondent $(2.4 \%)$ did not agree that the medical check is clear enough. For the assessment on nurses, one respondent $(2.4 \%)$ strongly disagreed and 1 respondent (2.4\%) disagreed that the nurses perform nursing care on time. Also, 1 respondent $(2.4 \%)$ strongly disagreed that the nurses/midwives perform midwifery/nursing care without differentiating patients' social status. One respondent $(2.4 \%)$ strongly disagreed that the patient admission procedure is easy and accessible. There was 1 respondent $(2.4 \%)$ who strongly disagree that the patients' data recording is done in a precise, detailed and thorough manner. Only 1 respondent $(2.4 \%)$ strongly disagreed and 3 respondents $(7.1 \%)$ did not agree that the staff pharmacists inform patients about the dose of drugs given. The last assessment of the reliability factor shows 2 respondents (4.8\%) did not agree that the drug purchasing service is precisely in order.

For the assurance factor, the overall results are the same as the assessment of the reliability factors. However, patients' expectations are higher than their assessment in the factor of doctors' skills. In addition, one respondent (2.4\%) strongly disagreed that the doctors' diagnosis was always correct. There was only one respondent $(2.4 \%)$ who disagreed that the administrative staffs accurately record patients' data.

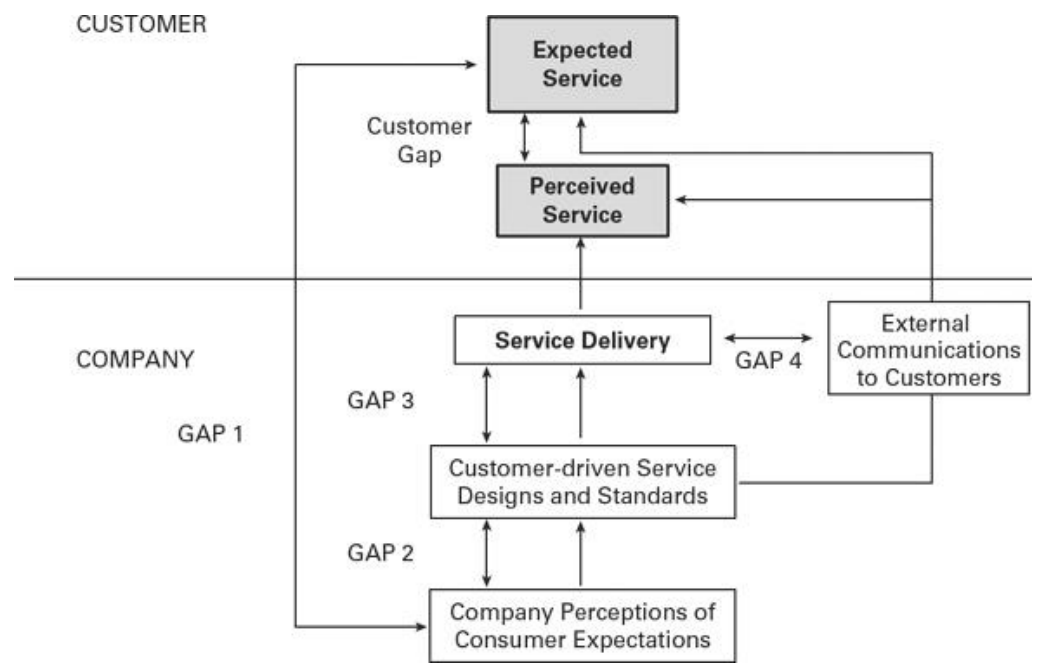

Figure 2. Gap Model of Service Quality (Source: Parasuraman et al. 1985)

Overall assessment on the tangible factor pointed out that patients' expectation is lower than their assessment. Nevertheless, 11 patients $(26.2 \%)$ disagreed that public facilities at the Hospital are complete. Meanwhile, there was only one respondent $(2.4 \%)$ who disagreed that the room cleanliness is well-maintained. In terms of medical equipment, only one respondent disagreed with it.

Patients' assessment of the empathy factor is higher than their expectations. Regarding their assessment of patience and politeness of staff pharmacists in responding to patients' questions, 11 patients $(26.2 \%)$ are against the statement. In addition, only one respondent $(2.4 \%)$ disagreed that doctors can understand patients' complaints and conditions.

The results also found that patients had higher assessment than what they expect in terms of responsiveness factor. Nonetheless, 10 patients $(23.8 \%)$ perceived that the staff pharmacists do not pay attention to the number, type and expirate date of drugs. In addition, one respondent $(2.4 \%)$ did not think that the doctors give clear and understandable information. Also, there was one respondent who did not agree that the doctors are responsive to patients' conditions.

Kotler in Peprah and Atarah (2014) explains that satisfaction is a person's pleasant and unpleasant feeling as a result of comparing service outcomes with their expectations. Customer satisfaction is described as a result of cognitive and affective evaluation in which the standard of comparison is determined and compared with what a person receives. When expectations outweigh the outcomes, customers will be dissatisfied and vise versa. While the assessment of services outweighs expectations, they will be in a neutral position. Several studies report that patient satisfaction is influenced by several critical factors, including nurses' attitude, service performance, information delivery skills, and the availability of sophisticated equipment. Other studies mention other factors, such as twenty-four opening hours, doctors' patience to explain patients' condition before treatment, ability to provide detailed information of the treatment, as well as the cleanliness and physical appearance of the hospital building. Parasuraman et al. in Peprah and Atarah (2014) explain that expectations outweighing assessment do not mean that services are not qualified. Rather, having the customers' expectations will improve the services in order to fulfill their expectations.

The respondents involved chose Kendangsari Merr Mother and Child Hospital for pregnancy care, such as pregnancy check-up, early initiation of breastfeeding, lactation classes, homecare, pregnancy exercise, pregnancy yoga, 
and laparoscopy. Other than that, they expect the Hospital to serve them friendly. In fact, the overall pregnancy care services at the Hospital is good and needs to improve.

Figure 2 depicts a gap model of service quality used to measure service quality. In this study, the customer gap is measured from the expectation and assessment. According to Jenkinson et al. in Al-Abri and Al-Balushi (2014), patient satisfaction indicates patients' attitudes towards services. While, Mohan et al. (2011) define patient satisfaction as emotions, feelings, and perceptions towards hospital services.

According to Kotler (1997), customer satisfaction is a feeling of pleasure or disappointment as a result of the impression of a product or service that fulfills the expectation. Further, Yazid (1999) explains customer satisfaction is the difference between expectations and outcomes of a product or service performance. Singh in Tjiptono (2000) states that if a customer is not satisfied, they can perform 3 responses. First, voice response occurs when an unsatisfied customer submits a complaint to a company. Second, private response means an unsatisfied customer submits a complaint to another person, whether a friend, colleague or family about a company's service or product. This response has a big impact on the company's image. The third is the third-party response, which customers complain through mass media, consumers' institutions, or legal institutions. The Kendangsari Merr Mother and Child Hospital have provided services for handling complaints. As a result, it minimizes a private response and third-party response.

Research shows that positive perceptions of service quality affect customers' intentions to act positively, such as praising, prioritizing, and increasing sales from a company even paying more expensive prices (Weitz and Wensley, 2002). Woodside, Frey, and Daly in Weitz and Wensley (2002) found a significant relationship between patient satisfaction and the desire to use the same hospital. While Cronin and Taylor (1192) found a positive correlation between service quality and customer satisfaction. Other studies have found a positive and significant relationship between customers' perceptions of service quality and their willingness to recommend a service to their relatives.

In relation to service quality and customer's intentions, Puay and Nelson in Yousapronpaiboon and Johnson (2013) suggest achieving service excellence, hospitals must continuously avoid errors in service. The assessment of hospital service quality may improve through good communication between patients and service providers (John in Yousapronpaiboon and Johnson, 2013). Aiken (2012) concludes that the community expects responsive service as a result of the performance of healthcare providers. In some countries, incentives have been given to accelerate patient satisfaction and patient-focused services. Al-Borie and Damanhouri (2013) concluded that inpatient services at private hospitals were more satisfying than at public hospitals as patients expect better services from private hospitals. As a relatively new private hospital, Kendangsari Merr Mother and Child Hospital have complete and comfortable facilities, and these may be some advantages for them to provide better services.

Arab (2012) explains that the relationship between service quality and patient loyalty proves the importance of improving service quality to attract and retain patients as well as expand market share. He also explained that in order to increase patient loyalty, improving the quality of services is highly recommended as it focuses on the rationalization of costs, punctuality of service, the accuracy of service, improvement of communication skills and interpersonal relationships of doctors, nurses, and other staffs. This is also in accordance with the results of this present study that one aspect to be addressed at Kendangsari Merr Mother and Child Hospital is the punctuality of service, especially doctors' schedules. In addition, the communication and interpersonal skills of doctors and nurses are important factors that can improve service quality.

Moreover, Abuosi and Atinga (2013) identify several components of service quality, such as technical and functional quality, patient quality, professional quality, quality management, clinical quality, and economic quality. Technical quality is related to the process and accuracy of diagnosis, while functional refers to the method of delivering health services. Patient quality means giving what the patient wants, and professional quality is giving what is needed by the patient. In addition, quality management means using as few resources as possible to meet patients' desires and needs without errors and delays. Clinical quality is related to illness, death and infection rates, while economic quality refers to the quality of care.

\section{CONCLUSION}

This study evaluated the services of Kendangsari Merr Mother and Child Hospital by using the parameters of Reliability, Assurance, Tangible, Empathy and Responsiveness (RATER). Overall, most of the respondents gave a good assessment of the Hospital's services. Patient satisfaction is the key to measure whether the assessment is good or not. Based on the survey results, there are several recommendations given to improve the Hospital's services. First, Kendangsari Merr Mother and Child Hospital should immediately develop grand service programs to compete with other similar hospitals. Second, the Hospital needs to evaluate medical services provided by doctors and nurses/midwives, availability of facilities, and administration services. Further study on patients' information sharing to their relatives and patient satisfaction related to the brand image of the Hospital is required to be done.

\section{REFERENCES}

Abuosi, A. A. and Atinga, R. A. (2013) 'Service quality in healthcare institutions: establishing the gaps for policy action', International Journal of Health Care Quality Assurance, 26(5), pp. 481-492. 
Aiken, L. H. et al. (2012) 'Patient safety, satisfaction, and quality of hospital care: cross sectional surveys of nurses and patients in 12 countries in Europe and the United States', BMJ, 344(e1717), pp. 1-14.

Al-Abri, R. and Al-Balushi, A. (2014) 'Patient Satisfaction Survey as a Tool Towards Quality Improvement', Oman Medical Journal, 29(1), pp. 3-7.

Al-Borie, H. M. and Sheikh Damanhouri, A. M. (2013) 'Patients' satisfaction of service quality in Saudi hospitals: a SERVQUAL analysis', International Journal Health Care Quality Assurance, 26(1), pp. 20-30.

Arab, M. et al. (2012) 'The Effect of Service Quality on Patient loyalty: a Study of Private Hospitals in Tehran, Iran', Iranian Journal Public Health, 41(9), pp. 71-77.

Atarah, B. A. and Awuah, A. (2014) 'Assessing the Influence of Advertising on Student Enrolment in Private Tertiary Institutions in Ghana', International Journal of Business and Social Research, 4(3), pp. 55-65.

Dinarsari, E., Supriyanto, S. and Rochmah, T. N. (2003) 'Analisis Kepuasan dan Harapan Pelanggan dalam Rangka Peningkatan Loyalitas Pelanggan Kelas Utama RS Panti Rahayu Purwodadi Grobogan', Jurnal Administrasi dan Kebijakan Kesehatan, 1(1), pp. 45-50.

Khanchitpol, Y. and William, C. J. (2013) 'Measuring hospital out-patient service quality in Thailand', Leadership in Health Services, 26(4), pp. 338-355.

Kotler, P. (1997) Manajemen Pemasaran. Jakarta: PT. Prenhallindo.

Narang, R. et al. (2015) 'Impact of hospital atmosphere on perceived health care outcome', International Journal of Health Care Quality Assurance, 28(2), pp. 129-140.

Parasuraman, A. and Zeithaml, V. A. (2002) 'Understanding and Improving Service Quality: A Literature Review and Research Agenda', in Weitz, B. A. and Wensley, R. (eds) Handbook of Marketing. California: SAGE Publications Ltd.

Tjiptono, F. (2000) Perspektif Manajemen dan Pemasaran Kontemporer. Jogjakarta: Penerbit Andi.

Yazid (1999) Pemasaran Jasa Konsep dan Implementasi. Yogyakarta: Penerbit Ekonisia.

Zeithaml, V. A., Parasuraman, A. and Berry, L. L. (2001) Delivering quality service: balancing customer perceptions and expectations. New York: Free Press. 